\title{
Extraction and Characterization of Silicon Dioxide from Volcanic Ash of Mount Sinabung, Indonesia: A Preliminary Study
}

\author{
Moraida Hasanah ${ }^{1,2}$, Timbangen Sembiring ${ }^{1 *}$, Zuriah Sitorus ${ }^{1}$, \\ Syahrul Humaidi', Fynnisa Zebua ${ }^{3}$, Rahmadsyah ${ }^{2}$ \\ 1 Doctoral Program in Physics, Faculty of Mathematics and Natural Sciences, University of North Sumatra, Jalan \\ Biotechnology No.1, Padang Bulan, Kec. Medan, 20155, Medan, Indonesia \\ 2 Department of Mechanical Engineering, Asahan University, Jalan Jend. Ahmad Yani, Kisaran Naga, Kisaran \\ Tim., Kisaran, North Sumatra 21216, Indonesia \\ ${ }^{3}$ Department of Civil Engineering, Asahan University, Jalan Jend. Ahmad Yani, Kisaran Naga, Kisaran Tim., \\ Kisaran, North Sumatra 21216, Indonesia \\ * Corresponding author's e-mail: timbangen@usu.ac.id
}

\begin{abstract}
The study was conducted on the extraction of volcanic ash from Mount Sinabung through the co-precipitation method to recover silicon dioxide $\left(\mathrm{SiO}_{2}\right)$. The X-ray fluorescence (XRF) analysis showed that the $\mathrm{SiO}_{2}$ content in volcanic ash was $48.5 \%$, and after extraction, it was $99.1 \%$. The morphology shown by scanning electron microscope (SEM) indicated that $\mathrm{SiO}_{2}$ looks cleaner and tends to be the same size compared to the volcanic ash sample. The average particle size of volcanic ash and extracted $\mathrm{SiO}_{2}$ were $32.28571 \pm 2.51259$ and $12.97521 \pm 0.60657 \mu \mathrm{m}$, respectively. The X-ray diffractometer (XRD) analysis showed that the crystal structure of the volcanic ash sample was quartz, maghemite, and cristobalite. Besides, the extracted $\mathrm{SiO}_{2}$ had an amorphous quartz crystal structure. The test conducted using Fourier transform infrared (FTIR) resulted in the absorption of $1095.57 \mathrm{~cm}^{-1}$ and $798.53 \mathrm{~cm}^{-1}$ for the $\mathrm{Si}-\mathrm{O}-\mathrm{Si}$ and $\mathrm{Si}-\mathrm{OH}$ groups which were the groups of siloxanes and silanols, respectively.
\end{abstract}

Keywords: volcanic ash, characterization, electron microscopy, Mount Sinabung, particle size distribution.

\section{INTRODUCTION}

Mount Sinabung is one of the active volcanoes in Indonesia which spewed hot clouds in mid-September 2013. The hot cloud conditions reached a temperature of $700^{\circ} \mathrm{C}$ and a distance of 4,500 meters which caused many villages around Mount Sinabung to be covered in thick volcanic ash for several months. During the eruption, people's livelihoods were disrupted by the explosive eruption of Mount Sinabung, which released much material in the form of volcanic ash and sand thrown as far as $5 \mathrm{~km}$ from the summit. Explosive eruptions involve the volcanoes which expel their materials into the air with a powerful eruption. These materials are in the form of clastic materials such as bombs (large lumps of rock), lapilli (small rocks such as gravel), and volcanic sand or ash.
Mount Sinabung ash is the ash produced from the eruption of Mount Sinabung, which replaces the properties and functions of cement after being mixed with additional chemicals. If the ash is used as an additive, it will make the concrete easier to mix, denser to water, more resistant to chemical factors, and reduce the expansion of concrete due to the alkaline silicate reaction process in the concrete mixture (Wijaya, 2018).

The abundance of volcanic ash material resulting from the eruption of Mount Sinabung is an interesting case to study. According to the tests that have been done using atomic absorption spectrophotometry (AAS), it was shown that the volcanic ash from Mount Sinabung contains $78.3 \%$ of $\mathrm{SiO}_{2}, 2.91 \%$ of $\mathrm{Fe}_{2} \mathrm{O}_{3}, 4.56 \%$ of $\mathrm{Al}_{2} \mathrm{O}_{3}$, $1.07 \%$ of $\mathrm{MgO}, 4.84 \%$ of $\mathrm{CaO}$ and $0.46 \%$ of $\mathrm{Na}_{2} \mathrm{O}$. Silicon dioxide $\left(\mathrm{SiO}_{2}\right)$ is one of the most 
abundant compounds in the volcanic ash of Mount Sinabung that have the potential to be used in a variety of needs. One of the ways to obtain high-purity of $\mathrm{SiO}_{2}$ involves extracting these compounds from the natural sample using the co-precipitation method (Hasanah et al., 2021).

The potential of natural resources as a source of silica has been widely studied and known. As one of the abundant metal oxides in volcanic ash, silica can be used as a primary material for synthesizing silica gel through the formation of alkaline silicate precursors. Sodium silicate can be converted into silica gel by condensation and hydrolysis using solvents, both polar and non-polar. By extracting silica in an alkaline state, sodium silicate will be formed. Sodium silicate will undergo a polymerization process to form silica gel at several different conditions of $\mathrm{pH}$ and solvent. Silica gel is one of the silica-based materials with broad uses, such as in the ceramic industry or special applications in the chemical field. Silica gel has a significant molecular weight and absorbs much water, which will cause the formation of a spongy solid (Maulida et al., 2017).

Silica, which consists of silicon and oxygen, can be obtained from mineral, vegetable, and crystalline silica synthesis. Mineral silica is a compound that is commonly found in mining or excavation materials in the form of quartz sand, granite, and feldspar (Gonçalves \& Bergmann, 2007). Silica is naturally found in crystalline and amorphous forms. Crystalline silica exists in three primary forms: quartz, tridymite, and cristobalite. The three general forms of crystalline silica are considered based on their stability to high-temperature increases. Each of the three forms mentioned before exhibits a change at high and low temperatures, where the structure is only slightly altered by a simple change in the orientation of the $\mathrm{SiO}_{2}$, which is tetrahedral relative to each other. The changes in shape at high temperatures have higher symmetry or smaller unit cells than at low temperatures (Purba, 2018).

The use of silica is extensive in the commercial industry. Quartz sand is the primary raw material in glass, ceramic, foundry, cement, tile, and silicon carbide abrasives (sandblasting). On the basis of the explanation above, the extraction and characterization of $\mathrm{SiO}_{2}$ gained from the volcanic ash of Mount Sinabung require investigation. This is a preliminary study supporting the further research on water treatment that will be conducted.

\section{METHODS}

This study uses a qualitative descriptive method that explains the results of the research procedure. The materials used in this study were the volcanic ash from Mount Sinabung. The technique used in this research involved the use of instruments in the laboratory such as scanning electron microscope (SEM), Fourier transform infrared spectroscopy (FTIR), X-ray diffractometer (XRD), and X-ray fluorescence (XRF).

The analysis technique goes through several stages of the process, each requiring the tools mentioned earlier. The procedure in this study consisted of two main steps: extraction and characterization of $\mathrm{SiO}_{2}$ from the volcanic ash sample. The sample was sieved with a 230 -mesh sieve to homogenize the size. The volcanic ash that has been sifted was taken in the amount of 50 grams, soaked with $\mathrm{HCl}$, and filtered. The sample was then washed and dried using an oven. After that, it was dissolved with $500 \mathrm{~mL}$ of $\mathrm{NaOH}$ and heated for 120 minutes, then filtered. The filtrate was tested gravimetrically. In this step, the filtered sample was sodium silica solution. Then, 8 $\mathrm{M}$ of $\mathrm{HCl}$ was dropped into the solution to form a white gel until $\mathrm{pH}$ of 7. Finally, the silica gel was deposited for 24 hours.

\section{RESULTS AND DISCUSSION}

The silicon dioxide $\left(\mathrm{SiO}_{2}\right)$ obtained from volcanic ash was characterized using several analytical instruments: SEM, FTIR, XRD, and XRF. The purposes of each instrument were as follows: (1) SEM was used to determine the morphology; (2) FTIR was applied to obtain the data about the functional groups; (3) XRD was used to describe the phase; and (4) XRF was applied to obtain the content information of oxide compounds. All of the instruments were applied to the volcanic sample before and after extraction.

\section{Morphology analysis}

Figure 1 shows morphological differences of the volcanic ash sample and the extracted $\mathrm{SiO}_{2}$. The volcanic ash particles look more random than ordinary ash particles. The shape looks sharper and jagged. This was caused by the enormous gas pressure from the magma extrusion process at Mount Sinabung (Latif et al., 2016). Those shapes 

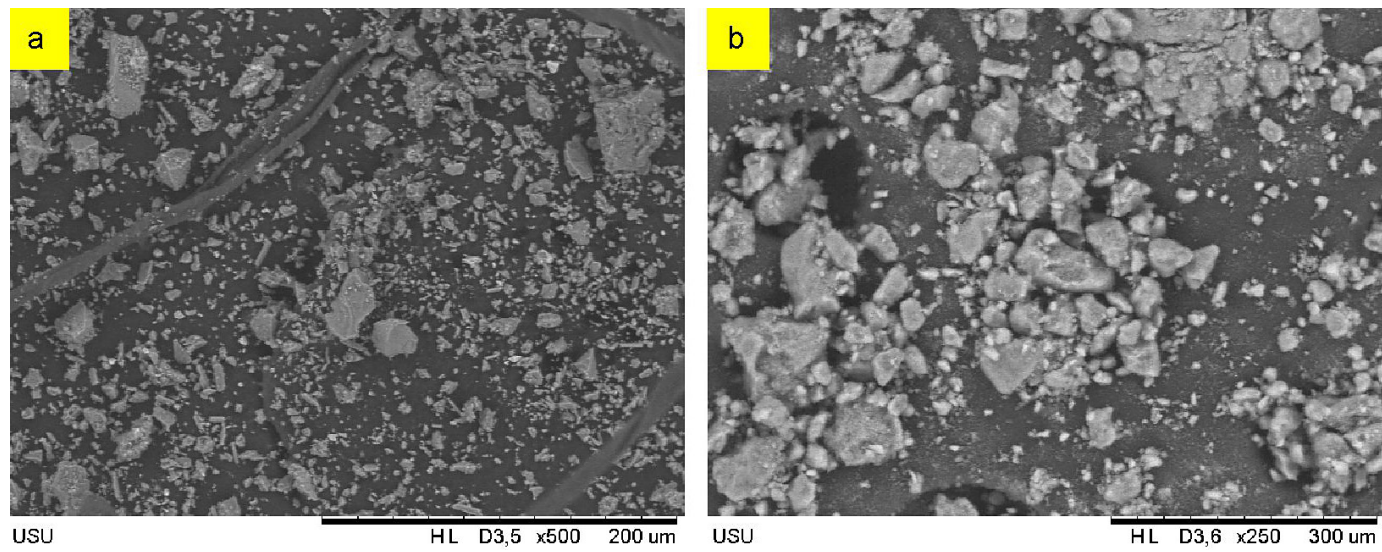

Figure 1. The morphology of (a) the volcanic ash of Mout Sinabung and (b) the extracted $\mathrm{SiO}_{2}$

of volcanic ash must be dangerous if inhaled, because they can cause lungs infection and eyes irritation (Sinuhaji, 2014). Moreover, the pores formed in the extracted $\mathrm{SiO}_{2}$ were also observed.

The $\mathrm{SiO}_{2}$ obtained from volcanic ash extraction was subjected to SEM analysis. The morphology of $\mathrm{SiO}_{2}$ looks cleaner, and the size tends to be the same. Using the Image $J$ software as shown in Figure 2, the size of the volcanic ash particles and $\mathrm{SiO}_{2}$ from the extraction of volcanic ash can be measured. The average particle size of volcanic ash and the extracted $\mathrm{SiO}_{2}$ are $32.28571 \pm 2.51259$ and $12.97521 \pm 0.60657$ $\mu \mathrm{m}$, respectively.

\section{FTIR characterization}

The absorption band of about $921 \mathrm{~cm}^{-1}$ on the volcanic ash spectra and $950 \mathrm{~cm}^{-1}$ on the extracted
$\mathrm{SiO}_{2}$ are related to the stretching vibration of the Si-O-Al bond (Alraddadi \& Assaedi, 2020).

The appearance of stretching and bending vibration of the $\mathrm{O}-\mathrm{H}$ group is due to the presence of water molecules and silanol groups $(\mathrm{Si}-\mathrm{OH})$ which are still contained, both in the volcanic ash before and after extraction (Liu et al., 2019; Utari et al., 2020).

On the basis of Table 1, the formation of sodium silicate $\left(\mathrm{Na}_{2} \mathrm{SiO}_{3}\right)$, which indicates the presence of the $\mathrm{Si}-\mathrm{OH}$ group, gives absorption at wavenumbers of $787 \mathrm{~cm}^{-1}$ and $802 \mathrm{~cm}^{-1}$. The reaction mechanism for the formation of $\mathrm{Na}_{2} \mathrm{SiO}_{3}$, as shown in Figure 4, begins with the excitation of hydroxyl ion $(-\mathrm{OH})$ in the silicon. In this reaction, one oxygen atom is released and forms $\mathrm{SiO}_{2} \mathrm{OH}^{-}$which is unstable. $\mathrm{SiO}_{2} \mathrm{OH}^{-}$undergoes the release of hydrogen atoms (dehydrogenation) to form $\mathrm{SiO}_{3}^{2-}$ and bonds with hydroxyl ions $(\mathrm{O}-\mathrm{H})$ to form water molecules $\left(\mathrm{H}_{2} \mathrm{O}\right) . \mathrm{Na}^{+}$from
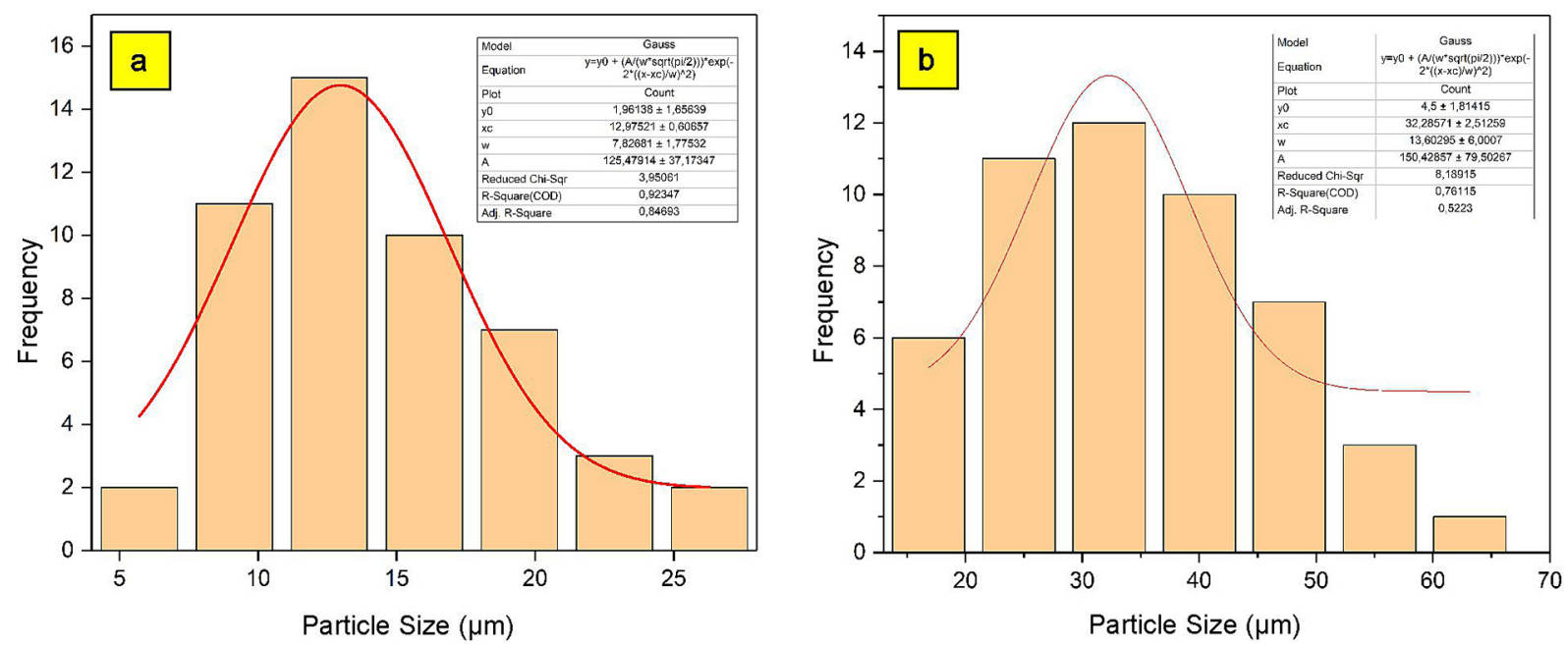

Figure 2. Particle size distribution of (a) volcanic ash sample from Mount Sinabung and (b) the extracted $\mathrm{SiO}_{2}$ 


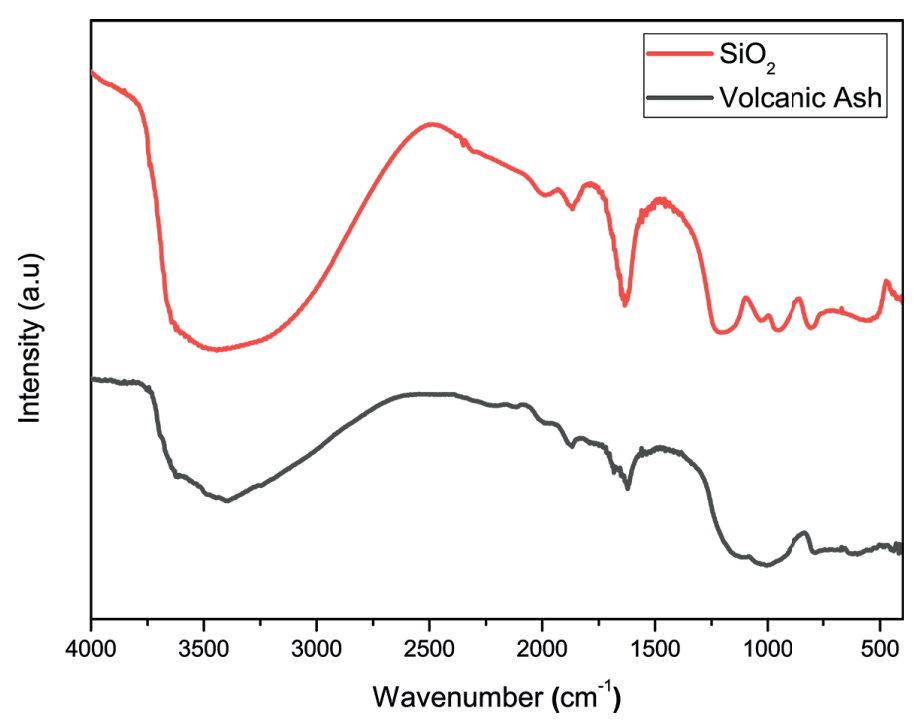

Figure 3. FTIR spectra of volcanic ash and $\mathrm{SiO}_{2}$

Table 1. Functional groups interpretation of volcanic ash sample (before and after extraction)

\begin{tabular}{|c|c|c|}
\hline \multirow{2}{*}{ Functional groups } & \multicolumn{2}{|c|}{ Wavenumber $\left(\mathrm{cm}^{-1}\right)$} \\
\cline { 2 - 3 } & $\begin{array}{c}\text { Before } \\
\text { extraction }\end{array}$ & $\begin{array}{c}\text { After } \\
\text { extraction }\end{array}$ \\
\hline O-H (stretching) & 3396 & 3451 \\
\hline O-H (bending) & 1622 & 1632 \\
\hline Si-O-Si (stretching) & 1008 & 1030 \\
\hline Si-O-Al (stretching) & 921 & 950 \\
\hline Si-OH (stretching) & 787 & 802 \\
\hline Si-O (stretching) & 545 & 555 \\
\hline
\end{tabular}

sodium hydroxide $(\mathrm{NaOH})$ and $\mathrm{SiO}_{3}{ }^{2-}$ anions will form $\mathrm{Na}_{2} \mathrm{SiO}_{3}$.

The absorption peaks at 1008 and $1030 \mathrm{~cm}^{-1}$ are associated to the functional groups of $\mathrm{Si}-\mathrm{O}-$ $\mathrm{Si}$, which are siloxane groups. The absorption peaks of 545 and $555 \mathrm{~cm}^{-1}$ are attributed to the $\mathrm{Si}-\mathrm{O}$ functional group of the siloxy. The reaction mechanism for the formation of $\mathrm{SiO}_{2}$ is shown in

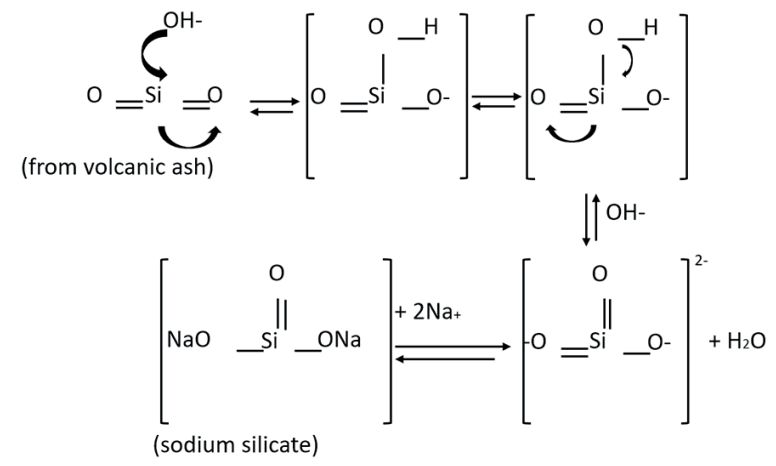

Figure 4. The reaction mechanism in the formation of sodium silicate $\left(\mathrm{Na}_{2} \mathrm{SiO}_{3}\right)$
Figure 5. $\mathrm{Si}-\mathrm{O}$ and $\mathrm{Si}-\mathrm{O}-\mathrm{Si}$ functional groups were formed when hydrochloric acid $(\mathrm{HCl})$ was dropped into $\mathrm{Na}_{2} \mathrm{SiO}_{3}$ to produce $\mathrm{SiO}_{2}$ and form $\mathrm{Si}-\mathrm{O}-\mathrm{Si}$ functional groups (Caroles, 2019). During the process, $\mathrm{Na}^{+}$will bind with $\mathrm{Cl}^{-}$to form $\mathrm{NaCl}$ salts which are dissolved in water and leave an $\mathrm{Si}(\mathrm{OH})_{4}$ precipitate. The addition of acid causes the $\mathrm{O}-\mathrm{H}$ group to detach and form a siloxane bond. The more acid added, the more siloxane bonds formed, which finally resulted in silica gel formation. The silica gel formed was washed until neutral using distilled water to remove the remaining acid and salt. The silica gel was then dried to obtain solid $\mathrm{SiO}_{2}$.

\section{XRD analysis}

The results of XRD analysis are featured using the Match 2 software as a diffractogram. There are three crystal structures observed using XRD, specifically quartz $\left(\mathrm{SiO}_{2}\right)$, maghemite $\left(\mathrm{Fe}_{2} \mathrm{O}_{3}\right)$, and cristobalite $\left(\mathrm{SiO}_{2}\right)$ so that Mount Sinabung volcanic ash can be asserted as a polycrystalline material.

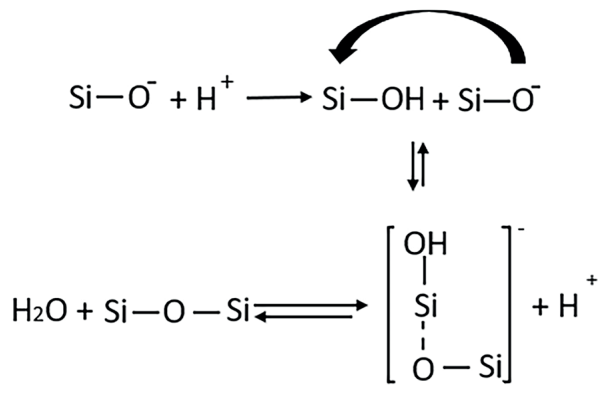

Figure 5. The reaction mechanism of $\mathrm{SiO}_{2}$ formation 
Figure 6 shows the diffractogram that was analyzed using the Match2 software. Quartz crystal structure according to COD:9012602 has a trigonal crystal system with lattice parameters of $\mathrm{a}=4.7050$ and $\mathrm{c}=5.2500$. Quartz is identified at angles of $2 \theta=21.84^{\circ}, 27.68^{\circ}$, and $42.20^{\circ}$ with Miller indices of (110), (011), and (111) (Tian et al., 2020). In turn, the maghemite structure, according to COD:9006317, has a cubic crystal system with lattice parameters of $a=8.3300$. Maghemite is identified at angles of $2 \theta=23.58^{\circ}$, $30.58^{\circ}$, and $35.58^{\circ}$ with Miller indices of (201), (202), and (311) (Lemougna et al., 2011). According to COD:9009685, the crystal structure of cristobalite has a tetragonal crystal system with lattice parameters of $\mathrm{a}=4.9570$ and $\mathrm{c}=6.8903$. Cristobalite is identified at an angle of $2 \theta=31.42^{\circ}$ with Miller index of (012). The emergence of the crystal structure of quartz and cristobalite is due to the temperature difference in the magma body of Mount Sinabung. The high-temperature forms the cristobalite structure, and the lower one forms the quartz structure. The three crystal structures appeared according to the XRF analysis, which represent $\mathrm{SiO}_{2}$ and $\mathrm{Fe}_{2} \mathrm{O}_{3}$ as the highest content in the volcanic ash sample.

The XRD test results for $\mathrm{SiO}_{2}$ from the extraction of volcanic ash showed amorphous properties (Amin et al., 2016). This can be seen from the peak that is wide and not sharp.
Figure 7 shows the crystal structure of $\mathrm{SiO}_{2}$ as quartz. The quartz crystal structure according to COD:9012605 has a trigonal crystal system with lattice parameters of $\mathrm{a}=4.5350$ and $\mathrm{c}=5.1700$. Quartz is identified at an angle of $2 \theta=22.74^{\circ}$ with a Miller index of $(100)$. The absence of other crystal peaks indicates the purity of the $\mathrm{SiO}_{2}$ obtained from volcanic ash extraction (Dubey et al., 2015).

\section{XRF analysis}

$\mathrm{XRF}$ is an instrument used to characterize the content of metallic elements and metal oxides in the samples. There was a color change in the sample before and after extraction. Before extraction, the volcanic ash sample was gray, and after extraction, the volcanic ash of Mount Sinabung turned white.

Table 2 shows the volcanic ash content with $\mathrm{SiO}_{2}$ as the most abundant (48.5\%). It indicates that the volcanic ash from Mount Sinabung is a raw material that can be used to yield $\mathrm{SiO}_{2}$. A chemical process was carried out using the coprecipitation method to obtain $\mathrm{SiO}_{2}$. This is a consecutive method to obtain metal deposits and remove impurities from the material. The following is the reaction that occurs in the volcanic ash sample during the extraction using the co-precipitation method:

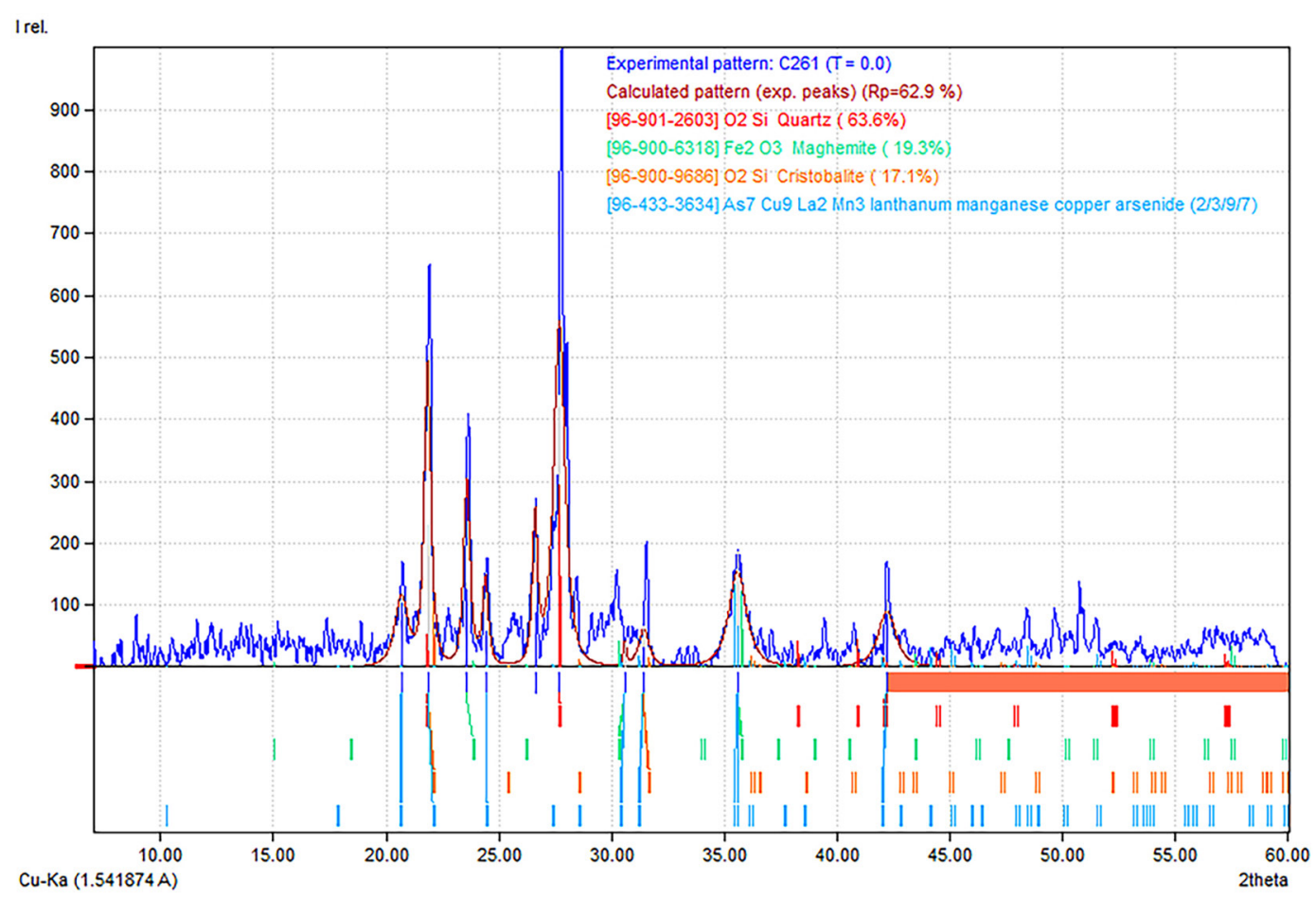

Figure 6. Diffractogram of volcanic ash processed using the Match2 software 


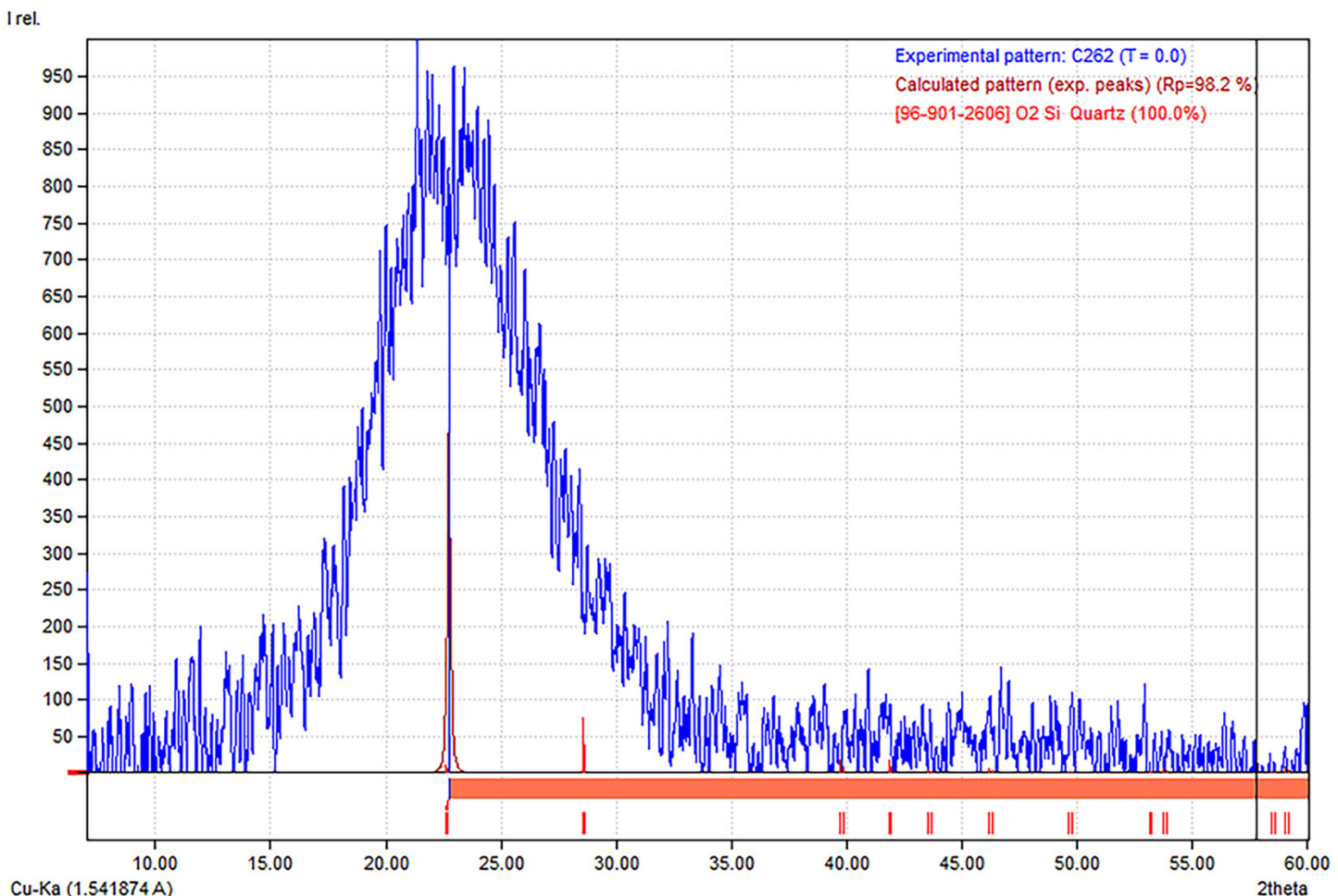

Figure 7. Diffractogram of the extracted $\mathrm{SiO}_{2}$ from volcanic ash processed using the Match2 software

Table 2. Compositions of the volcanic ash sample from Mount Sinabung

\begin{tabular}{|c|c|}
\hline Compounds & $\%$ \\
\hline $\mathrm{SiO}_{2}$ & 48.5 \\
\hline $\mathrm{Fe}_{2} \mathrm{O}_{3}$ & 15.5 \\
\hline $\mathrm{Al}_{2} \mathrm{O}_{3}$ & 12 \\
\hline $\mathrm{CaO}$ & 11.1 \\
\hline $\mathrm{SO}_{3}$ & 6.7 \\
\hline $\mathrm{K}_{2} \mathrm{O}$ & 2.71 \\
\hline $\mathrm{MoO}_{3}$ & 1.7 \\
\hline $\mathrm{TiO}_{2}$ & 1.25 \\
\hline $\mathrm{SrO}$ & 0.21 \\
\hline $\mathrm{MnO}_{2}$ & 0.17 \\
\hline $\mathrm{Re}_{2} \mathrm{O}_{7}$ & 0.1 \\
\hline $\mathrm{BaO}_{2}$ & 0.06 \\
\hline $\mathrm{V}_{2} \mathrm{O}_{5}$ & 0.056 \\
\hline $\mathrm{CuO} \mathrm{Cr}_{2}$ & 0.051 \\
\hline $\mathrm{ZnO}$ & 0.042 \\
\hline & 0.008 \\
\hline
\end{tabular}

$$
\begin{gathered}
\mathrm{SiO}_{2(\mathrm{~s})}(\text { volcanic ash })+\mathrm{NaOH}_{(\mathrm{aq})} \rightarrow \mathrm{Na}_{2} \mathrm{SiO}_{3(\mathrm{aq})}+\mathrm{H}_{2} \mathrm{O}_{(\mathrm{aq})} \\
\mathrm{Na}_{2} \mathrm{SiO}_{3(\mathrm{aq})}+\mathrm{H}_{2} \mathrm{O}_{(\mathrm{aq})}+2 \mathrm{HCl}_{(\mathrm{aq})} \rightarrow \mathrm{Si}(\mathrm{OH})_{4(\mathrm{aq})}+2 \mathrm{NaCl}_{(\mathrm{aq})} \\
\mathrm{Si}(\mathrm{OH})_{4(\mathrm{aq})} \rightarrow \mathrm{SiO}_{2(\mathrm{~s})}+\mathrm{H}_{2} \mathrm{O}_{(\mathrm{aq})}
\end{gathered}
$$

$\mathrm{HCl}$ solution performs as a precipitation agent. $\mathrm{SiO}_{2}$ compounds are easily soluble in alkaline solutions and precipitate in acidic solutions. Therefore, to gently extract the $\mathrm{SiO}_{2}$ compound from the volcanic ash, an alkaline solvent such as $\mathrm{NaOH}$ solution was used. Following that, an acid solution of $\mathrm{HCl}$ was used to form deposit. The deposit was dried in an oven to free $\mathrm{SiO}_{2}$ from water (Agung $\mathrm{M}$ et al., 2013). The addition of $\mathrm{HCl}$ solution is intended to dissolve the metal oxide compounds contained in the volcanic ash to reduce and eliminate the metal oxide content (Naufal et al., 2013).

On the basis of Table 3 , it was known that the $\mathrm{SiO}_{2}$ level increased while other oxides decreased after the extraction process. The value of the $\mathrm{SiO}_{2}$ content is found to be $99.1 \%$. Hence, it can be concluded that the co-precipitation method is reliable to recover $\mathrm{SiO}_{2}$ and remove other metal oxides or impurities from volcanic ash samples.

\section{CONCLUSIONS}

This study found that XRF could give the information about the $\mathrm{SiO}_{2}$ content in volcanic ash samples before and after extraction, the values of which were $48.5 \%$ and $99.1 \%$, respectively. This means that the co-precipitation method was 
Table 3. Compositions of volcanic ash after extraction

\begin{tabular}{|c|c|}
\hline Compounds & $\%$ \\
\hline $\mathrm{SiO}_{2}$ & 99.1 \\
\hline $\mathrm{Fe}_{2} \mathrm{O}_{3}$ & 0.357 \\
\hline $\mathrm{CaO}$ & 0.35 \\
\hline $\mathrm{TiO}_{2}$ & 0.069 \\
\hline $\mathrm{Cr}_{2} \mathrm{O}_{3}$ & 0.025 \\
\hline $\mathrm{NiO}$ & 0.006 \\
\hline $\mathrm{Eu}_{2} \mathrm{O}_{3}$ & 0.069 \\
\hline $\mathrm{Yb}_{2} \mathrm{O}_{3}$ & 0.03 \\
\hline $\mathrm{CuO}$ & 0.031 \\
\hline
\end{tabular}

successful in extracting $\mathrm{SiO}_{2}$. In addition, the characterization by other instruments shows that the volcanic ash sample is a polycrystalline material, as shown by the XRD results. Meanwhile, the characterization results using FTIR can explain the reaction mechanism about the formation of $\mathrm{SiO}_{2}$ during the extraction process. The particle size distribution was described using SEM, both before and after the extraction of the volcanic ash sample, with values of $32.28571 \pm 2.51259$ and $12.97521 \pm 0.60657 \mu \mathrm{m}$, respectively.

\section{Acknowledgements}

We want to thank Universitas Sumatera Utara and Universitas Asahan for their support in this research.

\section{REFERENCES}

1. Agung M.G.F., Hanafie Sy M.R., Mardina P. 2013. Ekstraksi Silika Dari Abu Sekam Padi Dengan Pelarut Koh, Konversi, 2(1), 28. https://doi.org/10.20527/k.v2i1.125

2. Alraddadi S., Assaedi H. 2020. Characterization and potential applications of different powder volcanic ash. Journal of King Saud University - Science, 32(7), 2969-2975. https://doi.org/10.1016/j. jksus.2020.07.019

3. Amin N., Khattak S., Noor S., Ferroze I. 2016. Synthesis and characterization of silica from bottom ash of sugar industry. Journal of Cleaner Production, 117, 207-211. https://doi.org/10.1016/j. jclepro.2016.01.042

4. Caroles, J.D.S. 2019. Ekstraksi Silika yang Terkandung Dalam Limbah Abu Terbang Batu Bara. Fullerene Journal of Chemistry, 4(1), 5.

5. Dubey R.S., Rajesh Y.B.R.D., More M.A. 2015. Synthesis and Characterization of SiO2 Nanoparticles via Sol-gel Method for Industrial Applications.
Materials Today: Proceedings, 2(4-5), 3575-3579. https://doi.org/10.1016/j.matpr.2015.07.098

6. Gonçalves M.R.F., Bergmann C.P. 2007. Thermal insulators made with rice husk ashes: Production and correlation between properties and microstructure. Construction and Building Materials, 21(12), 2059-2065. https://doi.org/10.1016/j. conbuildmat.2006.05.057

7. Hasanah M., Sembiring T., Sebayang K. 2021. Extraction of Silica Dioxide (SiO2) From Mount Sinabung Volcanic Ash with Coprecipitation Method. Materials Science and Engineering, 0-5. https:// doi.org/10.1088/1757-899X/1156/1/012015

8. LatifD.O., Rifa'IA., Suryolelono K.B. 2016. Chemical characteristics of volcanic ash in indonesia for soil stabilization: Morphology and mineral content. International Journal of GEOMATE, 11(4), 26062610. https://doi.org/10.21660/2016.26.151120

9. Lemougna P.N., MacKenzie K.J.D., Melo U.F.C. 2011. Synthesis and thermal properties of inorganic polymers (geopolymers) for structural and refractory applications from volcanic ash. Ceramics International, 37(8), 3011-3018. https://doi.org/10.1016/j. ceramint.2011.05.002

10. Liu Y., Zeng F., Sun B., Jia P., Graham I.T. 2019. Structural Characterizations of Aluminosilicates in Two Types of Fly Ash Samples from Shanxi Province, North China. Minerals, 9(6), 358. https://doi. org/10.3390/min9060358

11. Maulida, Ginting M., Wici H. 2017. Ekstraksi Abu Vulkanik Gunung Sinabung Untuk Menghasilkan Silika Gel. Jurnal Teknik Kimia USU, 6(3), 41-46. https://doi.org/10.32734/jtk.v6i3.1588

12. Naufal A., Putra H.E., Tjahjanto R.T., Misbah M.K. 2013. Optimasi Ekstraksi Silika Dan Alumina Dari Lumpur Sidoarjo. In Universitas Brawijaya Malang, 2(1).

13. Purba M.L. 2018. Pengaruh Penambahan TiO2 Terhadap Luas Permukaan dan Ukuran Pori dari Silika Abu Vulkanik Gunung Sinabung, Universitas Sumatera Utara: Medan [Skripsi].

14. Sinuhaji P. 2014. Identifikasi Logam Berat Debu Vulkanik Gunung Sinabung di Daerah Perteguhen Kabupaten Karo. Jurnal Biotropikal Sains, 11(2), 51-54.

15. Tian W., Du B., Shui A., Ke S., Shan Q., He C., Ma J. 2020. Template-free preparation of humidity self-regulating silica-based mesoporous oxide from volcanic ash. Journal of Sol-Gel Science and Technology, 94(2), 416-424. https://doi.org/10.1007/ s10971-020-05258-3

16. Utari N.P.S.N., Sudiarta I.W., Suarya P. 2020. Sintesis Dan Karakterisasi Silika Gel Dari Abu Vulkanik Gunung Agung Melalui Teknik Sol-Gel. Jurnal Kimia, 30. https://doi.org/10.24843/JCHEM.2020. v14.i01.p06 